\title{
Prevalence of the Beta Case in Variants among Tharparkar, Rathi, Sahiwal, Kankrej and Cross Breed and its Influence under Selective Pressure
}

\author{
Mrinalini Saran ${ }^{1}$, Ankita Gurao ${ }^{1}$, Rajeev Kumar Joshi ${ }^{2}$ and S.K. Kashyap ${ }^{1}$ \\ ${ }^{1}$ Department of Veterinary Microbiology and Biotechnology, ${ }^{2}$ Department of Animal Genetics \\ and Breeding, RAJUVAS, Bikaner, India \\ *Corresponding author
}

\section{A B S T R A C T}

\begin{tabular}{|c|c|}
\hline $\begin{array}{l}\text { Key w ord s } \\
\text { Beta-casein, A2 } \\
\text { type milk, Cross- } \\
\text { bred, Bos indicus }\end{array}$ & $\begin{array}{l}\text { Milk has been regarded as wholesome food since centuries. The major milk proteins are } \\
\text { the casein }(80 \%) \text { and the whey proteins }(10 \%) \text {. One of the prominent milk proteins in } \\
\text { cattle i.e. beta casein, is encoded by highly polymorphic genes, leading to formation of } 12 \\
\text { protein variants. Among them A1 and A2 variant are the most frequent; the A2 being the } \\
\text { primitive type present in Bos indicus at higher percentage than Bos taurus. Most of the }\end{array}$ \\
\hline Articl & eta- \\
\hline $\begin{array}{l}\text { Accepte } \\
15 \text { Febr } \\
\text { Availab } \\
10 \text { Mar }\end{array}$ & $\begin{array}{l}\text { The following study has been conducted to concisely predict the diminishing percent of A2 } \\
\text { allele in the cross-bred Rathi cattle herd in compared to the pure-bred Rathi and other } \\
\text { indigenous cattle and evaluate the change in A } 2 \text { allele frequency in course of generations. }\end{array}$ \\
\hline
\end{tabular}

\section{Introduction}

Milk has been regarded as a wholesome food and also an essential part of diet for both infants and adults. Worldwide the major sources of milk are cow, buffalo, goat, sheep and camel, contributing $85 \%, 11 \%, 2 \%, 1.4 \%$ and $0.2 \%$ of world milk production respectively. Cow contributes highest to the milk production i.e. 600 million tonnes $(83 \%$ of total milk produced) (1) of milk every year and with a herd capacity of total 264 million worldwide (1). The total milk production in India is highest in the world, approximately 182.16 million tonnes (2), 178 million cattle population. The world per capita milk availability was 322 gm/day (3) during 201415. Like any other developing country, the fluid milk consumption of India is higher than world average, thus again indicating the necessity to focus on milk consumption related health aspects.

The widely consumed cow milk has protein content $\sim 32 \mathrm{~g} / \mathrm{l}$, that forms the major portion of protein in diet of infants and lactovegetarians next to the legumes. The casein $(80 \%)$ is abundant among the protein fraction, comprising $\alpha$-casein (29\%), $\beta$-casein $(27 \%)$ and $\kappa$-casein $(10 \%)$. The gene coding for 
CSN2 gene ( $\beta$-casein) is present on BTA-6. Like all other milk proteins, beta -casein is highly polymorphic. Total of 49 milk protein variants have been reported by Farell et al., 2004. Till now 12 genetic variants (A1, A2, A3, B, C, D, E, F, H1, H2, I, G) have been reported for beta casein(4). The most common form of beta casein in dairy cattle breeds are A1 and A2, while B is less common and A3, C are rare (5). On the basis of their potential to release beta casomorphin-7, beta casein variants can be categorized as A1 type and A2 type, the previous one containing B,C,F,G and $\mathrm{D}$ variants, whereas the later category contains A3, E, D, H1, H2 and I (6). Among all the mutations occuring on beta casein, at 67th position of the protein a noteworthy mutation has lead to replacement of proline by histidine. The codon CCT (proline) was replaced by CAT (histidine) leading to formation of variant $\mathrm{A} 2$ and $\mathrm{A} 1$ respectively. Presence of histidine at $\mathrm{A} 1$ in contrast to proline in $\mathrm{A} 2$ makes it susceptible to gastrointestinal proteolytic digestion for releasing betacasomorphin-7 (BCM-7), which has been implicated in not only the type I diabetes and IHD (Ischaemic Heart Diseases) but also in several other non communicable diseases like SIDS (Sudden Infant Death Syndrome), schizophrenia, autism, milk related allergies (7) and arteriosclerosis (8). The epidemiological, in vivo and in vitro studies have concluded with both positive $(9,10)$ and negative correlation (11) of the A1/A2 milk consumption to the alleged health issues., This mutation also carry an evolutionary significance, the A2 being the primitive type present in Bos indicus at higher percentage than Bos taurus. The majority of taurine breeds domesticated in America, Europe and Australia (excluding Indian sub-continent, most of the African zebu and few Far-East countries) are taurine which has been bred selectively for higher milk production, leading to lower frequency of A2 allele (few exceptions e.g. Guernsey and Fleckvieh breed). Whereas the indicine cattle have evolved naturally without any selection pressure; thus, allowing them to carry higher frequency of A2 allele. The consumption of the A1 type milk in European population has been clearly associated with type I diabetes $(9,10,12$,$) , ischemic heart disease (12,10)$ and neurological disorders (13) by several epidemiological data. The following investigation has been done to estimate the diminishing A2 allele frequency among the indigenous cattle and cross-bred Rathi cattle in compared to the pure bred indigenous Rathi breed. This will aid in planning the breeding policies in future, so that the A2 gene pool remain conserved in the indigenous herd.

\section{Materials and Methods}

For the purpose of this work, Rathi pure breed, Sahiwal, Kankrej, Tharparkar and cross breed (Rathi $\times$ Holstein Fresian) were obtained from LRS (CVAS, Rajasthan University of Veterinary and Animal Sciences, Bikaner), LRS (Kodamdesar, Bikaner), LRS (Beechwal, Bikaner) and LRS (CVAS, Rajasthan University of Veterinary and Animal Sciences, Bikaner)., All the cattle were free of mastitis and blood was collected from juglar veins and genomic DNA was extracted on the same day using QIAamp® DNA mini kit (Qiagen). The DNA was then taken for purity and concentration check by the use of nanodrop device.

The ACRS-PCR and PCR-RFLP was performed using the primers described by Lien et al., (1992) and McLachlan (2006) respectively $(14,15)$.

CASB67: 5'-CCTGCAGAATTCTAGTCTA TCCCTTCCCTGGGCCCATCG-3'

CASB122:5'-GAGTCGACTGCAGATTT TCAACATCAGTGAGAGTCAGGCCCTG$3^{\prime}$ 
Csn4F: 5'-CCTTCTTTCCAGGATGAACTC CAGG-3'

Csndde4R: 5'-GAGTAAGAGGAGGGATGT TTTGTGGGAGGCTCT-3'

The primers CASB67 and CASB122 have been designed in such a way that so that upon amplification a restriction site for a taqI enzyme is created in the amplicon. The primers ( $\operatorname{csn} 4 \mathrm{~F}$ and $\operatorname{csnDde} 4 \mathrm{R}$ ) are designed to amplify the beta casein's exon $7^{\text {th }}$ and amplified product has the naturally occuring restriction site for DdeI enzyme. The PCRRFLP was only used for amplifying Sahiwal DNA. The PCR was performed by $200 \mathrm{ng}$ of genomic DNA in a $25 \mu \mathrm{l}$ reaction volume containing final volume of 5 pmol of primers, $200 \mu \mathrm{M}$ of each dNTP and $1 \mathrm{U}$ of Taq polymerase $\left(\mathrm{GoTaq}^{\circledR}\right.$ PCR Core System I Promega). The PCR cycles were as follows$95^{\circ} \mathrm{C}$ for $5 \mathrm{~min}$, and 30 cycles of $94^{\circ} \mathrm{C}$ for 1 min, $62^{\circ} \mathrm{C}$ for $45 \mathrm{sec}, 72^{\circ} \mathrm{C}$ for $30 \mathrm{sec}$ and final extension of $7 \mathrm{~min}$. For Csn 4F/ 4R primer pair the annealing temperature was of $58^{\circ} \mathrm{C}$ for $30 \mathrm{sec}$. The PCR was run on $2 \%$ agarose gel at $100 \mathrm{~V}$ for 1 hour to detect the product size of 251bp and $121 \mathrm{bp}$ for CASB67/122 (Fig no. 1(A)) and Csn4F/Dde4R (Fig no. 1(B)). The final product was cleaved in a $25 \mu$ l reaction involving $15 \mu \mathrm{l}$ of PCR product, $2.5 \mu \mathrm{l}$ of $10 \times$ NEB cutsmart buffer, $5 \mathrm{U}$ of TaqI enzyme for CASB67/122 primer product and 5U of DdeI (NEB \# R0175S) enzyme for Csn4F/Dde4R primer product and incubated for 20-25 minutes. The restricted products were resolved on 3\% gel (Fig. 2 and 3). The representative samples were sequenced from DNA sequencing facility (Department of Biochemistry, University of Delhi, South Campus).

\section{Results and Discussion}

The genomic DNA samples from Tharparkar, Sahiwal, Kankrej, cross breed and pure bred
Rathi were amplified using the ACRS-PCR and PCR-RFLP primers (Fig. 1(A) and Fig.1(B)) and digested using TaqI and DdeI enzyme (Fig. 2 and 3) respectively. The resultant RFLP pattern from TaqI was interfered to distinguish A1A1 genotype (213 bp), A2A2 genotype (251 bp) and A1A2 genotype (251 and $213 \mathrm{bp}$ ). Whereas the DdeI was interfered to distinguish A1A1 genotype (121 bp), A2A2 genotype (86, $35 \mathrm{bp)}$ and A1A2 genotype (121, 86, $35 \mathrm{bp})$. All the cattle of Tharparkar, Rathi and Kankrej breed displayed single band of $251 \mathrm{bp}$, indicating toward the A2A2 genotype on digestion with TaqI enzyme. Out of the 30 Sahiwal, 4 showed dual bands of $121 \mathrm{bp}$ and $86 \mathrm{bp}$, therefore indicating toward the A1A2 genotype (Fig.3 (A)). 10 samples of Rathi cross bred (Rathix Holstein Fresian) cattle examined with the DdeI which displayed only two bands of 86 and $35 \mathrm{bps}$, indicating them to be carrying A2A2 genotype (Fig.3 (B)). To determine the SNP at $875287\left(90^{\mathrm{th}}\right.$ position on $6^{\text {th }}$ chromosome that is comprised within $7^{\text {th }}$ exon of beta casein gene, we sequenced the samples that exceptionally displayed A1 allele. The sequencing results suggest occurrence of $\mathrm{C}$ to A allele change.

The mean allele frequency of A1 allele in Bos indicus has been reported as 0.98 (15), where in the present study has came with an unexpected A2 allele frequency of 0.825 (by Hardy Weinberg's Equation) and A1 allele frequency of 0.067 in pure bred Sahiwal cattle (Table 1). The amplicons showing A1 allele upon digestion with Ddel were sequenced (amplicons obtained from $\mathrm{Csn} 4 \mathrm{~F}$ and CsnDde4R primer set) to confirm the presence of A1 allele in Sahiwal cattle (Fig.4). The results conveyed the presence of CAT codon (SNP showing c.8101A $>\mathrm{C}$ in Fig. 4) in Sahiwal cattle showing A1A2 genotype upon digestion with DdeI enzyme. The sequenced amplicon were reconstructed (since the direct product obtained from the primer set 
contained mismatched bases) using reference sequence and aligned with bovine beta-casein gene, CDS (GenBank: M55158.1). It revealed a non synymous variation $(c .8131 \mathrm{~A}>\mathrm{T})$, corresponding to p.L92H variation (Lys to His) (Fig. 5). The Indian cattle have evolved naturally without selection pressure for milk production, different from the taurine cattle, which have been under intensive selection for milk production trait and it is quite possible that non random mating targeting for higher milk producing individuals has caused decrease in A2 allele frequency in the Sahiwal herd over the time (16).

Table.1 Genotype and allele frequencies among Indigenous cattle breed and cross breed (Rathi×HF)

\begin{tabular}{|c|c|c|c|c|c|}
\hline \multirow[t]{2}{*}{ Breed } & \multicolumn{3}{|c|}{ Genotype Frequency } & \multicolumn{2}{|c|}{ Gene Frequency } \\
\hline & Genotype & Number & $\begin{array}{l}\text { Genotype } \\
\text { frequency }\end{array}$ & Allele & Allele frequency \\
\hline \multirow[t]{2}{*}{ Rathi (30), } & A1A1 & 0 & 0 & A1 & 0 \\
\hline & A2A2 & 30 & 0.75 & A2 & 1 \\
\hline \multirow[t]{3}{*}{ Tharparkar (30), } & A1A1 & 0 & 0 & A1 & 0 \\
\hline & A1A2 & 0 & 0 & A2 & 1 \\
\hline & $\mathrm{A} 2 \mathrm{~A} 2$ & 30 & 1 & & \\
\hline \multirow[t]{3}{*}{ Kankrej (30) } & A1A1 & 0 & 0 & A1 & 0 \\
\hline & A1A2 & 0 & 0 & A2 & 1 \\
\hline & $\mathrm{A} 2 \mathrm{~A} 2$ & 30 & 1 & & \\
\hline \multirow{3}{*}{ Sahiwal (30) } & A1A1 & 0 & 0.04 & A1 & 0.067 \\
\hline & A1A2 & 4 & 0.124 & A2 & 0.933 \\
\hline & $\mathrm{A} 2 \mathrm{~A} 2$ & 26 & 0.871 & & \\
\hline \multirow[t]{3}{*}{ Cross breed (10) } & A1A1 & 0 & 0 & A1 & 0 \\
\hline & A1 A2 & 0 & 0 & A2 & 1 \\
\hline & $\mathrm{A} 2 \mathrm{~A} 2$ & 10 & 1 & & \\
\hline
\end{tabular}

Fig.1 (A,B)- Results of PCR for beta casein gene amplification using CASB67 and CASB122 primers and Csn4F and CsnDde4R primers for showing band of $251 \mathrm{bp}$ and $121 \mathrm{bp}(2.5 \%$ agarose)
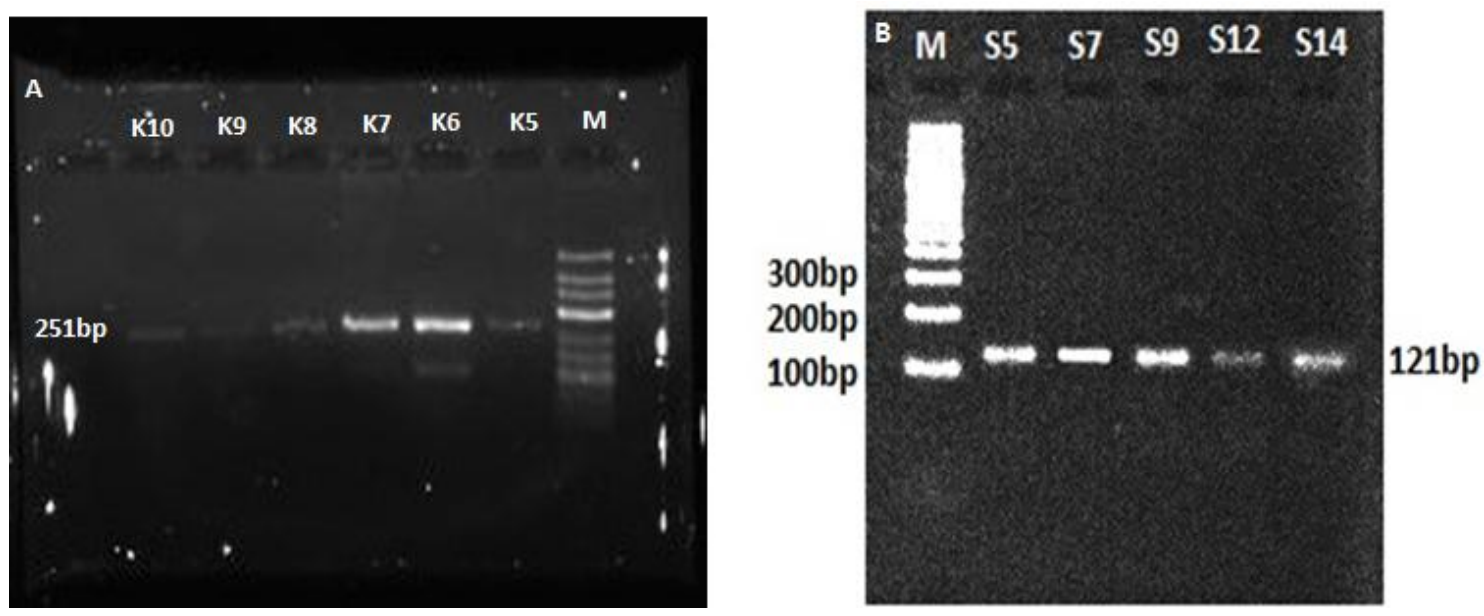
Fig.2 (A, B \& C). Amplification result of Bovine $\beta$-casein gene on 3\% agarose gel after Taq1 enzyme digestion. Line M display 100bp DNA marker. Genotypes of the samples are determined as $251 \mathrm{bp}$ and $116 \mathrm{bp}$ bands (A2A2 genotype)
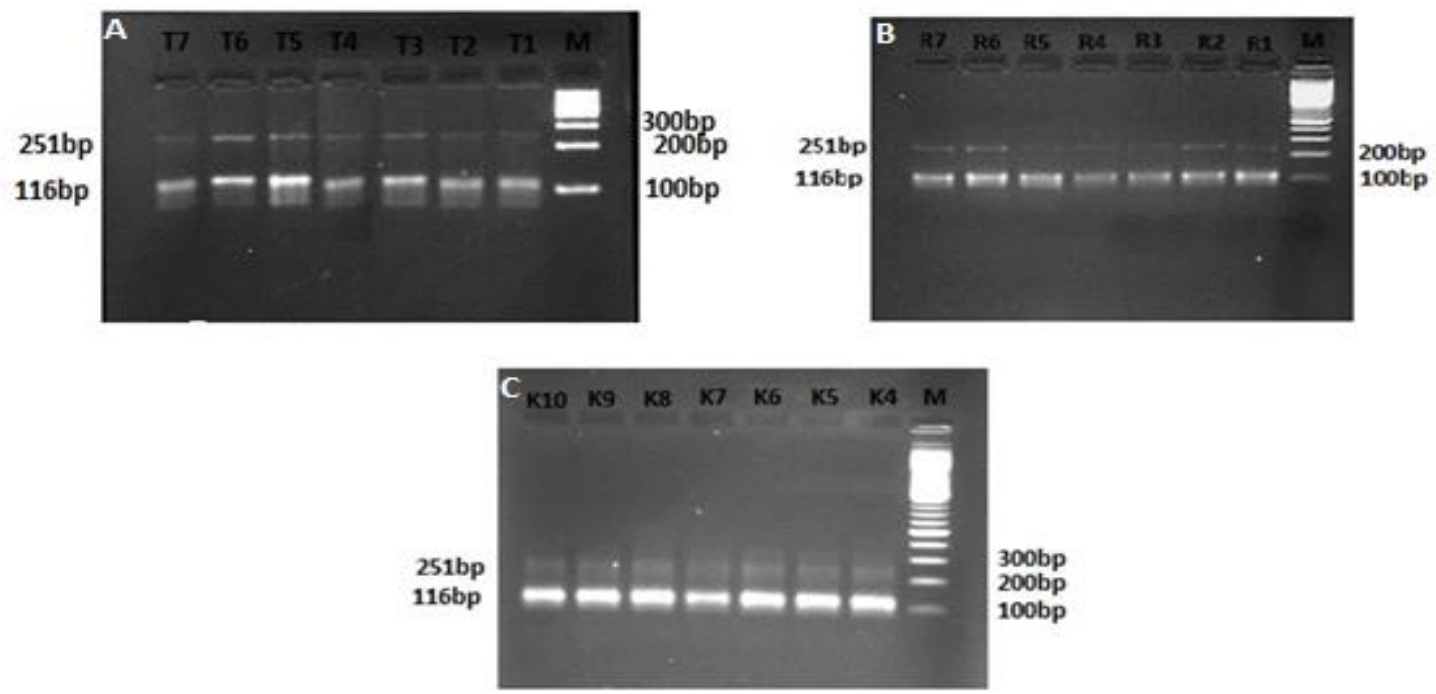

Fig.3 (A \& B). Digested product of Csn4F and CsnDde4R primer using Dde1 enzyme on 2.5\% agarose gel. Line M display 100bp DNA marker and the samples indicating with 121, 86 and 35 bp bands (A1A2 genotype) and 86bp and 35bp bands (A2A2 genotype)
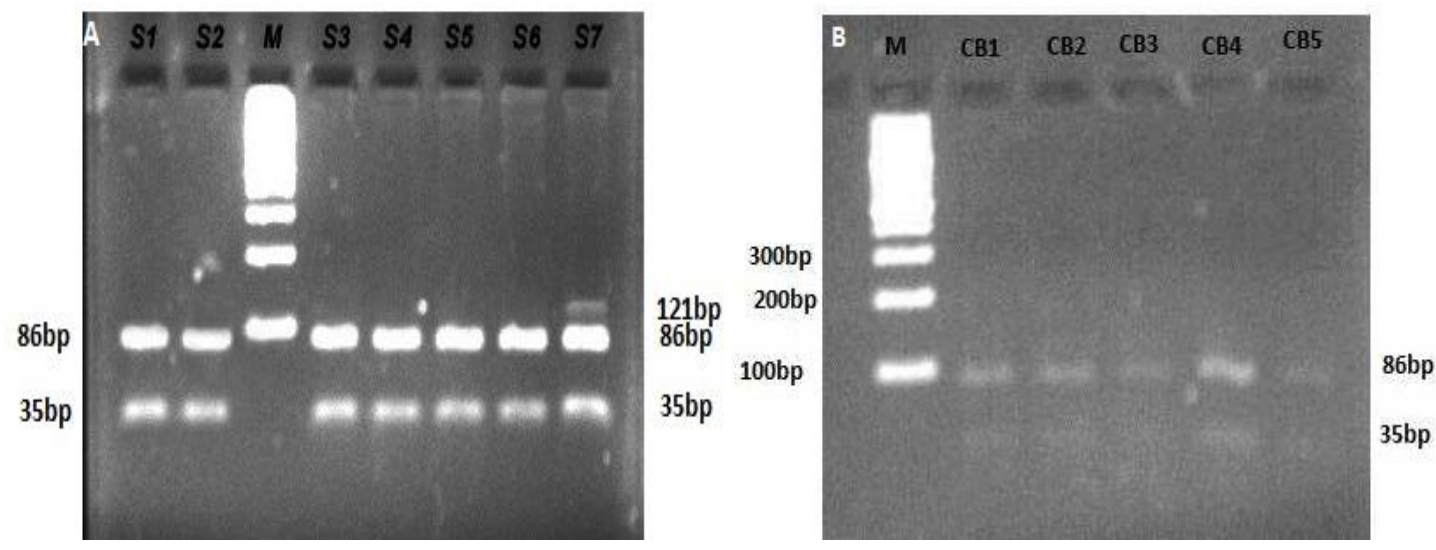

Fig.4 The chromatogram depicting the heterozygous allele (c.8101A $>$ C) in amplicon generated using Csn4F and Csndde4R primer set for Sahiwal cattle carrying A1 allele.

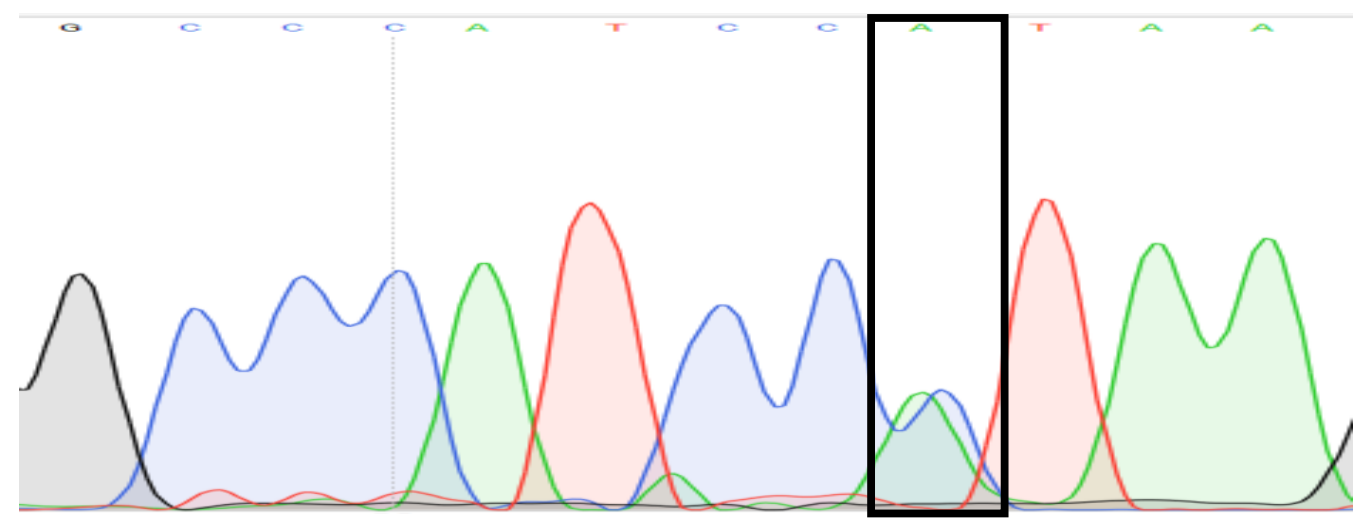


Fig.5 The alignment showing presence of CAT codon in both assemblies (Genbank ID:M5518 and amplicon obtained from Csn4F and Csndde4R primer set) in Sahiwal cattle showing A1 allele.

CsnDdeI

M5518

CsnDdeI

M5518
gatgaactccaggataaaatccacccetttgcccagacacagTCTCTAGTCTATCCCTTC

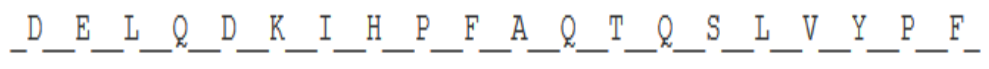

GATGAACTCCAGGATAAAATCCACCCCTTTGCCCAGACACAGTCTCTAGTCTATCCCTTC

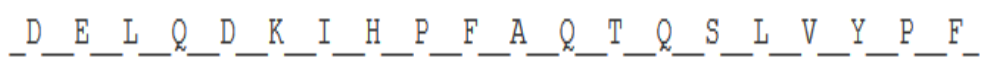

Also few numbers of sires when mated with disproportion amount of females may also affect the genotype of the next generation at a much higher rate than estimated according the Hardy Weinberg's principle.

In conclusion, the following study concluded the genotype present in the major cattle breeds of Western India including Tharparkar, Rathi, Kankrej, Sahiwal and cross-bred (Rathi×Holstein Fresian). The results for the Sahiwal were quite diverging from the earlier reports on the beta casein genotype of the bred, which were mentioned as A2A2 and in the present study conducted on 30 lactating cow of Sahiwal breed were found to be A2A2 and A1A2 genotypes. Furthermore all the cross breed (Rathi $\times$ Holstein Fresian) were of A2A2 gentype.

\section{Acknowledgement}

All the authors gratefully acknowledge financial support from Rajasthan University for Veterinary and Animal Sciences (RAJUVAS). The active assistance rendered by Prof. Rajeev Joshi, dairy in charge, LRS, CVAS, Bikaner is highly acknowledged.

\section{References}

1. http://faostat3.fao.org/browse/Q/QA/E. FAO stats, 2013- Livestock primary data.

2. http://www.nddb.org/information/stats. NDDB stats 2014-15

3. May 2012."Food Outlook - Global Market Analysis" Food and Agriculture Organization of the United Nations. pp. 8, 51-54.

4. Roginsky H, Encyclopedia of Dairy Sciences. Academic Press (2003), London.

5. 5) Farrell, H.M Jr., Jimenez-Flores R., Bleck G.T., Brown, E.M., Butler, J.E et $a l$, Nomenclature of the proteins of cows' milk sixth revision, $J$ Dairy $S c i$, 87(6)(2004), 1641-74.

6. 6) Kamiński S, Polymorphism of bovine 
beta-casein and its potential effect on human health, J Appl Genet Journal of Applied Genetics, 48 (2007) 189-98.

7. 7) Chatchatee $P$, Jarvinen K M, Bardina L, Vila L, Beyer $\mathrm{K}$ et al., (2001) Identification of $\mathrm{IgE}$ and $\mathrm{IgG}$ binding epitopes on $\beta$ and $\kappa$ casein in cow's milk allergic patient, Clin Exp Allergy Clinical Experimental Allergy, 31(2001) 1256262.

8. 8) Tailford K A, Berry C L, Thomas A C and Campbell $\mathbf{J} \mathbf{H}$, A casein variant in cow's milk is atherogenic, Atherosclerosis, 170(1)(2003) 13-19.

9. 9) Elliott R B, Harris D P, Hill J P, Bibby $\mathrm{N} \mathrm{J}$ and Wasmuth HE, Type I (insulindependent) diabetes mellitus and cow milk: casein variant consumption, Diabetologia, 42(8): (1999) 1032.

10. 10) McLachlan $C N$ S, $\beta$-casein A1, ischaemic heart disease mortality, and other illnesses, Medical Hypotheses, 56(2)(2001), 262-27.

11. 11) Truswell A $S$, The A2 milk case:a critical review, Eur J Clin Nutr., 59(2005) 623-31.

12. 12) Laugesen $M$, Elliott $R$, Ischaemic heart disease, Type I diabetes and cow milk A1 beta casein, $N Z$ Med $J$. 116(2003) 1168.

13. 13) Reichelt KL, Landmark J, Specific IgA antibody increases in schizophrenia, Biological Psychiatry 1995; 37(6(1995) 410-13.

14. 14) Lien $S$, Aleström $P$, Klungland $H$, Rogne S, Detection of multiple betacasein (CASB) alleles by amplification created restriction sites (ACRS), Animal Genetics. 23(1992): 333-8.

15. 15) McLachlan $\mathrm{C} N$, Breeding and milking cows for milk free of $\beta$-casein A1, United States Patent 7094949 (2006).

16. 16) Mishra B P, Manishi M, Prakash B, Sodhi M, Kapila R et al, Status of milk protein, beta casein variants among Indian milch animals, Indian J. anim. Sci., 79(7) (2009): 722-725.

\section{How to cite this article:}

Mrinalini Saran, Ankita Gurao, Rajeev Kumar Joshi and Kashyap, S.K. 2019. Prevalence of the Beta Case in Variants among Tharparkar, Rathi, Sahiwal, Kankrej and Cross Breed and its Influence under Selective Pressure. Int.J.Curr.Microbiol.App.Sci. 8(03): 1842-1848. doi: https://doi.org/10.20546/ijcmas.2019.803.218 